\title{
Drug Evaluation Steps of Ministry of Health Drug Formulary in Saudi Arabia
}

\begin{abstract}
Yousef Ahmed Alomi*, (iD The Former General Manager of General Administration of Pharmaceutical Care, The Former Head, National Clinical Pharmacy and Pharmacy Practice, The Former Head, Pharmacy R and D Administration, Ministry of Health, Riyadh, SAUDI ARABIA. Saeed Jamaan Alghamdi, General Administration of Pharmaceutical Care, Ministry of Health, Riyadh, SAUDI ARABIA. Radi Abdullah Alattyh, General Administration of Pharmaceutical Care, Ministry of Health, Riyadh, SAUDI ARABIA.
\end{abstract}

\section{Correspondence:}

Dr. Yousef Ahmed Alomi, The Former General Manager of General Administration of Pharmaceutical Care, The Former Head, National Clinical Pharmacy and Pharmacy Practice, The Former Head, Pharmacy R and D Administration, Ministry of Health, Riyadh, SAUDI ARABIA.

Phone no: +966504417712 E-mail:yalomi@gmail.com

Received: 16-11-2018;

Accepted: 27-12-2018

Copyright: ๑ the author(s),publisher and licensee Pharmacology, Toxicology and Biomedical Reports. This is an open-access article distributed under the terms of the Creative Commons Attribution NonCommercial License, which permits unrestricted non-commercial use, distribution, and reproduction in any medium, provided the original work is properly cited.

This is an open access article distributed under the terms of the Creative Commons Attribution-NonCommercial-ShareAlike 4.0 License

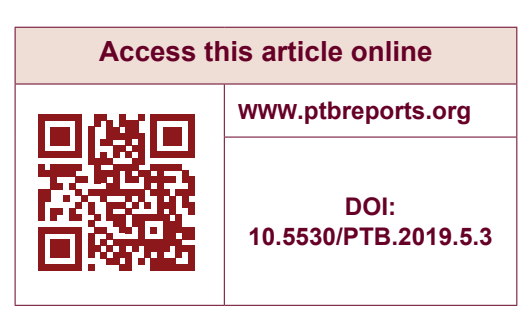

\begin{abstract}
Objective: To illustrate the Drug Evaluation Steps of Ministry of Health Drug Formulary at Health care institutions in the Kingdom of Saudi Arabia. Method: It is description analysis of Drug Evaluation Steps of drug information service at the Ministry of Health of Health institutions. The modified pharmacy business model system and Project Management Procedure used in the report. Results: The Drug Evaluation Steps established with a defined vision, mission and goals. The system human or economic and other resources described in the review. The risk management was discussed to assure the continuation of the system. Besides, the monitoring and controlling of the system as illustrated. The closing stage with convention to operation project demonstrated in the analysis. Conclusion: The drug evaluation steps system implemented and it is considered as part of the health care system and drug information centers regulations. The drug evaluation Steps needs the continuous updating accordingly at all Ministry of Health strategic planning in the Kingdom of Saudi Arabia.

Key words: Drug Evaluation, Steps, Ministry of Health, Drug Formulary, Saudi Arabia.
\end{abstract}

\section{INTRODUCTION}

All medications show both benefits for management of the patients and associate with problems related. ${ }^{1,2}$ Recently, drug-related problems and mortality have become extremely dangerous to the public. ${ }^{3-8}$ It is affecting patient safety and causes more economic burden on the healthcare system. ${ }^{9-12}$ In order to prevent drug-related problems, the healthcare team, including the pharmacist, should choose the best medications for patient which might show greater efficacy and safety. ${ }^{1,2}$ The medications are chosen through PTC, ${ }^{13}$ which is the official committee to regulate the addition or deletion of medications from hospital's drug formulary. The PTC is responsible for setting up guidelines or procedures for selecting the appropriate medications for inclusion in drug formulary. ${ }^{13}$ The corporate PTC establishes steps for selecting medications through best practice. Several pharmaceutical associations have established the regulations and guidelines for the same. ${ }^{14-18}$ Each method of selecting medications is based on previous guidelines or practices. The GAPC with drug information teams tried to include international guidelines and scoring system for the drug evaluation. ${ }^{19}$ To the best of our knowledge, there are no studies conducted in the KSA, Gulf and Middle Eastern countries. Therefore, in this study, we aimed to explore the steps of drug evaluation for addition or deletion from $\mathrm{MOH}$ drug formulary in the KSA.

\section{MATERIALS AND METHODS}

\section{Method of development of the project}

The drug formulary task force committee consisted of expert people from the pharmacies of the $\mathrm{MOH}$ hospital, primary healthcare centers and dental centers to perform drug evaluation for addition or deletion from the $\mathrm{MOH}$ drug formulary. The first author of this article headed the taskforce committee; he conducted regular periodical meetings. The committee utilized the pharmacy procedures of addition or deletion of medication to $\mathrm{MOH}$ drug formulary made some evidence based management guidelines of the diseases in $\mathrm{MOH}$ hospitals. In this study, we collaborated with the College of Pharmacy, Purdue University, USA, to obtain procedures and drug information. In addition, we used the international business model, pharmacy guidelines and project management institution guidelines of a new project. ${ }^{20-23}$ The prepared draft was sent to several reviewers, who corrected and updated it. Then, the second draft was submitted to the reviewers again for their final comments and approval. This took around 3 months to complete the task. The GAPC at the MOH sent the final document to all the hospitals for implementation. The drug formulary consisted of several parts including the initial phase, planning phase, execution phase and monitoring and controlling phase.

Initial phase

\section{Assessment needs}

In order to avoid low effectiveness of medications, all drugs must be evaluated for addition or deletion in the drug formulary. Each healthcare institution has a different method of evaluation. There are unified steps for drug evaluation at $\mathrm{MOH}$ institutions. In addition, it is tool of an educational or training program delivered to the pharmacist about this issue. 


\section{SWOT analysis}

In this project, we performed SWOT analysis. The strengths of this project were unified effective steps for addition or deletion of medications to the drug formulary at all $\mathrm{MOH}$ institutions; furthermore, scientific process of addition or deletion medications used in the healthcare institutions prevent the additional cost of ineffective medications. The weak points of this project were long time taken for the addition or deletion of medications and for education and training required in this process. The opportunities of this project were the implementation of healthcare and Saudi New Vision 2030, local and international accreditation standards, monitoring of cost management and management of control in the health insurance. The threat to this project will be privatized healthcare institutions without drug formulary.

\section{Market Analysis}

Several governmental and private hospitals developed their drug evaluation steps for addition or deletion medications from hospital formulary. Most of the healthcare institutions implemented drug evaluation steps based on the American Society of Health-System Pharmacist (ASHP). ${ }^{24}$ All of those experiences not published yet except from King Abdulaziz medical city. ${ }^{25}$ All those formats were manual written documentation. The practice demand to unified steps of drug evaluation steps for $\mathrm{MOH}$ drug formulary. The electronic format should be designed to make the life easy and better for documentation system in the Ministry of Health institutions.

\section{Planning phase \\ Scope of the project}

The steps of drug evaluation of addition or deletion from $\mathrm{MOH}$ drug formulary consisted of a general review of new medication, its clinical efficacy and safety, medications safety process and pharmacoeconomic aspect of the new drugs. Furthermore, the comparison between the new drugs with the previous drugs in the formulary or new drugs resembling a previous one indicates that the drug is marketed in Saudi Arabia or in rest of the world.

\section{Vision, Mission and Goals of the project}

Vision of this project is drug evaluation of addition or deletion of new medications to the $\mathrm{MOH}$ drug formulary at $\mathrm{MOH}$. The mission of this project is to provide the evidence based steps for the drug evaluation system at $\mathrm{MOH}$ institution in the Kingdom of Saudi Arabia. The goals

of this project are to unify the steps of drug evaluation process at $\mathrm{MOH}$ institution and provide the evidence based procedures of drug evaluation analysis, provide cost-effective medications to the $\mathrm{MOH}$ formulary and prevent any additional un-necessary of medications related addition to the $\mathrm{MOH}$ formulary.

\section{Project description}

All the drug information pharmacists or clinical pharmacists should be aware of following policies:

1. If the PTC needs to add or delete any medication or nutrition support products, then the concerned pharmacist should fill the drug evaluation form for addition or deletion.

2. The drug information pharmacist or clinical pharmacist should utilize drug evaluation formulary addition or deletion form (appendix 1) and complete the following information:

\section{- General information}

- Drug information

- Comparative with previous medications

- Medication safety
- Summary of published evidence (efficacy and safety)

- Summary of pharmacoeconomic studies

- Summary of cost analysis

- Summary of pharmacoeconomic drug-related problem analysis

- Utility rank

- Conclusion

3. The caregiver should take approval and signature from the hospital and regional PTC

4. The form should be sent to the corporate PTC for final approval

5. If the drug has been approved for addition into the MOH drug formulary, then the medicine should be ranked based on its therapeutic and economic value.

\section{Planning cost management}

This project required finance for the education and training of pharmacy staff and clinical pharmacist, to maintain electronic library, electronic documentation of drug evaluation through any database system and for the annual celebration of the best drug evaluation among pharmacist and clinical pharmacist.

\section{Execution phase}

\section{Management team}

The management team responsible for the follow-up of drug evaluation and documentation is the drug information services committee. The central committee designed through the GAPC at $\mathrm{MOH}$; The committee consisted of representatives from each region specialized in medications safety. Another regional committee established for each part included representatives from each hospital and primary healthcare center. All committees have a monthly meeting to discuss the drug evaluation status of new medications and update the $\mathrm{MOH}$ drug formulary. These activities should be reported to the corporate PTC at $\mathrm{MOH}$ for the final decision.

\section{Education and training}

The project needs educational courses on a regular basis on the steps involved in the process of drug evaluation for addition and deletion from $\mathrm{MOH}$ drug formulary; these courses have to be conducted through the GAPC at MOH and RAPC and involve drug information pharmacist, staff pharmacist and clinical pharmacist at $\mathrm{MOH}$ hospitals.

\section{Risk Management}

The risk management is divided into six parts: scope risks, personal risks, technical risks, budget risks, quality risks and schedule risks. Scope risks involve the pharmacist not being able to follow exact steps of drug evaluation; the pharmacist may take action by accepting and rejecting medications without final approval. The pharmacist should follow all steps and regulations of the drug evaluation process. The personal risks included the required workforce to implement the project which a highrisk impact and high priority and the team should send a member to analyze the number of pharmacy staff required based on the demand of the workforce. All concerned committees should send members to their related departments and human resources to request the number of pharmacy staff required based on the demand for the project. All personnel pertaining to this project need education and training, which is a high-impact and medium-priority requirement. All management teams should collaborate with human resources to set up an education plan with cost coverage.Technical risks in this project includes designing of the electronic system of the drug evaluation system. This risk is a highimpact and high-priority risk. The information technology personnel in all the concerned committees should set up an action plan for all the per- 
sonnel who are related to the project and propose the necessary budget and obtain approval from all the related departments. This might help to overcome the risk. Moreover, the education and training of the new computer system is another risk, which is a high-impact and high-priority risk. The concerned committee should collaborate with the information technology department and human resources department to avoid this risk. Budget risks includes the educational and training courses of the project, which is a high-impact and high-priority risk. The team should cover all topics that are needed to prevent this risk. The second type of budget risk is travel and accommodation, which is again a highimpact and high-priority risk. The team should obtain permission from the higher committee to avoid this risk. Both these risks are acceptable. Quality risks includes the KPIs not reaching the optimal levels. This risk is very high-impact and high-priority risk. All committees and management teams should review all the process of the project implementation and discuss with all staff members about the results of the KPIs and set up a solution for that the risks. Schedule risks includes the delay in the implementation of an action plan from management teams or pharmacy staff. This is a high-impact and high-priority risk. The central committee of the project should closely monitor all project-related activities and visit all regions periodically to take care of the implementation.

\section{Monitoring and controlling phase}

\section{Project Quality management}

The following KPIs of drug evaluation system were established to monitor the implementation at $\mathrm{MOH}$ institution. The adherence documentation of drug evaluation process; litterateur comparisons of safety, efficacy and economy; drug evaluation analysis with detailed information; the reporting rate of acceptance or rejection; and the number of medications added without registration in SFDA, US FDA or UK. ${ }^{26,27}$

\section{The closing of the project}

The steps of addition or deletion of drug from drug formulary at $\mathrm{MOH}$ institution is very crucial to control cost-effective medications in the KSA. The annual report of new drugs added to the $\mathrm{MOH}$ drug formulary should be prepared. Education and training courses should be provided to the healthcare providers on a regular basis regarding updating of new medications and drug regulation. In the future, further project needed to expand and include cost avoidance impact of adding new drugs and nutrition support medicines in the future. Annual celebration with the involving members of the project should also be conducted.

\section{ACKNOWLEDGEMENT}

I want to thank all inventory management and medical supply pharmacists at all regions for their cooperation.

\section{CONFLICT OF INTEREST}

None.

\section{ABBREVIATIONS}

KPIs: Key performance indicators; KSA: Kingdom of Saudi Arabia; MOH: Ministry of Health; PTC: Pharmacy and therapeutic committee; RAPC: Regional administration of pharmaceutical care; GAPC: General administration of pharmaceutical care; SFDA: Saudi Food and Drug Authority; US FDA: Unites States Food and Drug Administration; UK: United Kingdom.

\section{ORCID ID}

Yousef Ahmed Alomi (iD https://orcid.org/0000-0003-1381-628X

\section{REFERENCES}

1. AHSP. ASHP statement on pharmaceutical care. Am J Hosp Pharm. 1993;50(50):1720-3.

2. American Society of Health-System Pharmacists. ASHP guidelines on a standardized method for pharmaceutical care. Am J Heal Pharm. 1996;53(14):17136 .

3. Van-Den BPMLA, Egberts TCG, De Jong-Van DBLTW, Brouwers JRBJ. Drugrelated problems in hospitalised patients. Drug Safety. 2000;22(4):321-33.

4. Middleton J, McGrail S, Stringer K. Drug related deaths in England and Wales. BMJ. 2016;355:i5259.

5. Prot-Labarthe S, Di Paolo ER, Lavoie A, Quennery S, Bussières JF, Brion F, et al. Pediatric drug-related problems: A multicenter study in four French-speaking countries. Int J Clin Pharm. 2013;35(2):251-9.

6. Al-Olah YH, Al Thiab KM. Admissions through the Emergency Department due to Drug-Related Problems. Ann Saudi Med . 2008;28(6):426-9.

7. Alghamdy MS, Randhawa MA, Al-Wahhas MH, Al-Jumaan MA. Admissions for drug-related problems at the Emergency Department of a University Hospital in the Kingdom of Saudi Arabia. J Family Community Med. 2015;22(1):44-8.

8. Emergency department visits and admissions due to drug related problems at Riyadh military hospital (RMH), Saudi Arabia. Saudi Pharm J. 2014;22(1):17-25.

9. Bootman J, Johnson JA. Drug-related morbidity and mortality: A cost-of-illness model. Arch Intern Med. 1995;155(18):1949-56.

10. Ernst FR, Grizzle AJ. Drug-related morbidity and mortality: Updating the costof-illness model. J Am Pharm Assoc (Washington, DC1996) . 2001;41(2):192-9.

11. Alomi YA, Al-Shaibani AS, Alfaisal G, Alasmi NM. Cost Analysis Of Drug-Related Probelms In Saudi Arabia, Patient And Health Care Professional's Perspective. Value Heal. 2017;20(9):A669.

12. Watanabe JH, Mclnnis T, Hirsch JD. Cost of Prescription Drug-related Morbidity and Mortality. Ann Pharmacother. 2018;52(9):829-37.

13. Linda ST, Sabrina WC, Russel MJ, et al. ASHP Guidelines on the Pharmacy and Therapeutics Committee and the Formulary System. Am J Heal Pharm. 2008;65(13):1272-83

14. Andersen JM, Ostry S, Uhl HS, Smith RE. Evaluation of a limited drug for mulary in an adult internal medicine clinic. Amreican $\mathrm{J}$ of Hospital Phamacy. 1982;39(7):1184-6.

15. Schiff GD, Galanter WL, Duhig J, Koronkowski MJ, Lodolce AE, Pontikes P, et al. A prescription for improving drug formulary decision making. PLoS Med. 2012;9(5)

16. Glazer J, Huskamp HA, McGuire TG. A Prescription for Drug Formulary Evaluation: An Application of Price Indexes. Forum Health Econ Policy. 2012;15(2).

17. Seigfried RJ, Corbo T, Saltzberg MT, Reitz J, Bennett DA. Deciding which drugs get onto the formulary: A value-based approach. Value Heal. 2013;16(5):901-6.

18. Persson EL, Miller KS, Nieman JA, Sgourakis AP, Akkerman SR. Formulary evaluation using a class review approach: experience and results from an academic medical center. PT. 2013;38(4):213-6.

19. Lim TM, Ibrahim MI. Evaluation of angiotensin II receptor blockers for drug formulary using objective scoring analytical tool. Pharm Pract (Granada). 2012;10(3):136-42.

20. McDonough R. Writing a Business Plan for a New Pharmacy Service. The Dynamics of Pharmaceutical Care: Enriching Patients' Health. 2010;23.

21. Harris IM, Baker E, Berry TM, Halloran MA, Lindauer K, Ragucci KR, et al. Developing a Business-Practice Model for Pharmacy Services in Ambulatory Settings. Pharmacotherapy. 2008;28(2):7e-34e.

22. Sachdev G. Sustainable business models: Systematic approach toward successful ambulatory care pharmacy practice. Am J Heal Pharm. 2014;71(16):1366-74.

23. PMBOK Guide. A Guide to the Project Management Body of Knowledge. $6^{\text {th }}$ Edit. Project Management Institute, Inc. 2017.

24. American Society of Health-System. ASHP Guidelines on the Pharmacy and Therapeutics Committee and the Formulary System. Am J Heal Pharm. 2008;65:1272-83.

25. Carolina L, Esba A, Almodaimegh $H$, Cardiology B, Alhammad A, Ferwana M. P and T Committee Drug Prioritization Criteria: A Tool Developed by a Saudi Health Care System. Pharmacy and Therapeutics. 2018;43(5):293-300.

26. Alomi YA, Alghamdi SJ, Alattyh RA. Strategic Plan of General Administration of Pharmaceutical Care at Ministry of Health in Saudi Arabia 2012-2022. JPharm Pharm Scien. 2015;1(13):1-8.

27. Alomi Y. National Pharmacy Administration Programs. BAOJ Pharm Sci. $2015 ; 1(2): 1-2$ 


\section{APPENDIX:1}

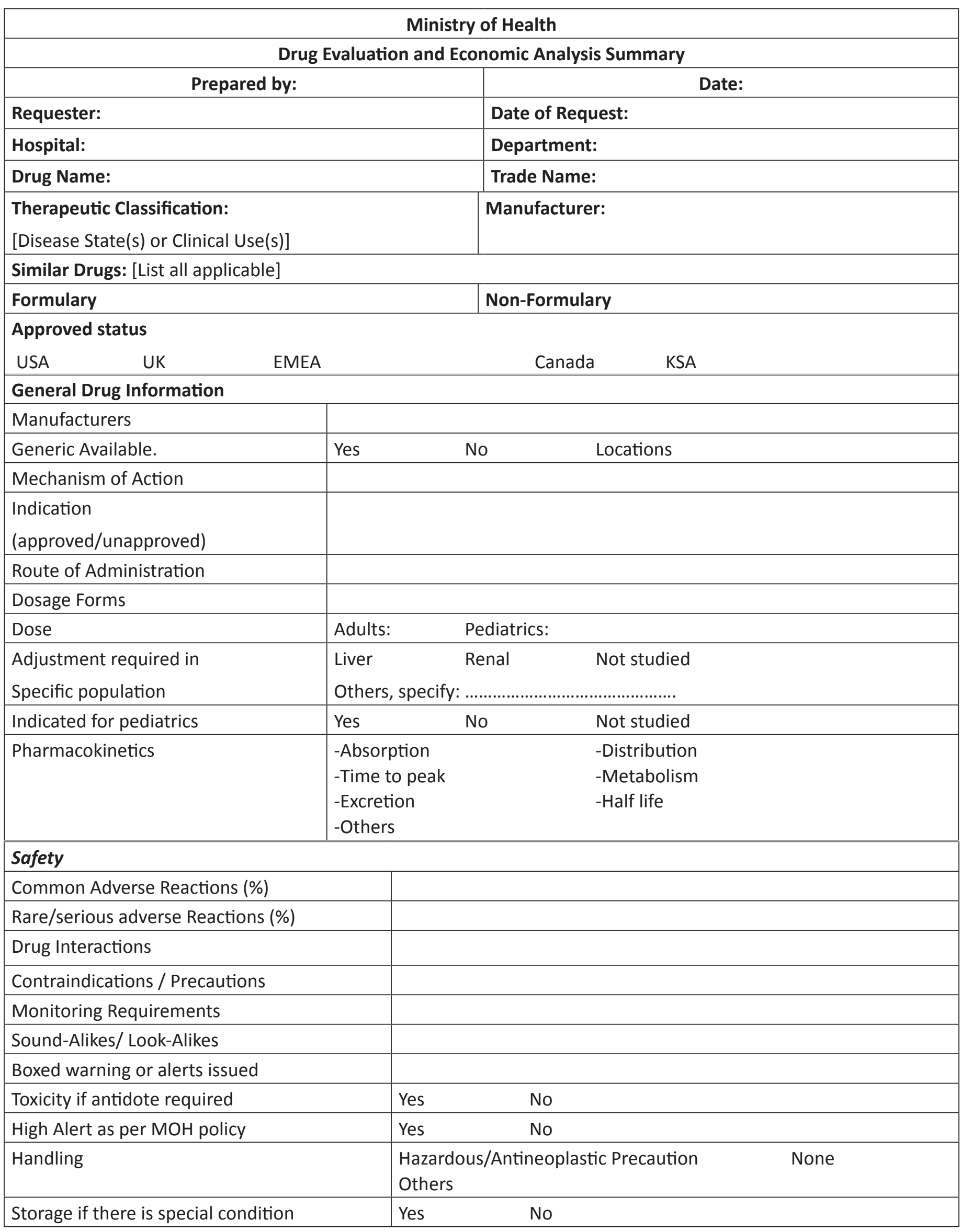


Table 1: Summary of Published Evidence (Efficacy and Safety).

\begin{tabular}{|c|c|c|c|c|c|c|c|c|}
\hline Ref. & Design* & $\begin{array}{c}\text { Drug } \\
\text { Regimens }\end{array}$ & n. & Duration & End Points & Demog. & Results/Comments & NNT \\
\hline & & 1. & & & 1. & & & \\
\hline 2 & & 2. & & & 2. & & & \\
\hline 3 & & 1. & & & 1. & & & \\
& & 1. & & & 1. & & & \\
\hline 4 & & 2. & & & 2. & & & \\
\hline 5 & & 2. & & & 1. & & & \\
\hline
\end{tabular}

Study design abbreviations: $\mathrm{DB}=$ Double Blind, $\mathrm{RCT}=$ Randomized Control Trial, $\mathrm{PC}=$ Placebo Controlled, $\mathrm{PG}=\mathrm{Parallel}-$ Group, $\mathrm{XO}=$ Crossover, $\mathrm{Mc}=$ Multi-center

Number needed to treat; only calculated if $P$ value $<0.05$; i.e., statistically significant NNT $=1 /$ Absolute risk reduction Evidence grades:

I- from meta-analysis or systematic review of randomized controlled trials (RCT's)/ large multicenter RCT's;

II- from one or more RCT;

III- from controlled trials without randomization; cohort, case control, analytic studies, multiple time series, before and after studies (preferably from more than one center or research group);

$I V$ - from other observational studies;

$V$ - from opinions of respected authorities based on clinical experience, descriptive studies or reports of expert committees.

Table 2: Summary of Pharmacoeconomic Studies.

\begin{tabular}{|c|c|c|c|c|c|c|}
\hline Ref. & Drug/Treatment Arms & $\mathrm{n} / \mathrm{D}^{*}$ & Method* & $\begin{array}{c}\text { Outcome } \\
\text { Measures }\end{array}$ & $\begin{array}{c}\text { Cost } \\
\text { Measures }\end{array}$ & Results/Comments \\
\hline 1 & 1. & & & 1. & & \\
\hline 2. & 1. & & 2. & \\
\hline 3 & 2. & & 1. & & \\
& 2. & & & 2. & & \\
\hline
\end{tabular}

${ }^{*} \mathbf{n} / \mathbf{D}^{*}$ : Number of patients/ Duration of the study

${ }^{*}$ Method abbreviations: $\mathrm{CEA}=$ cost - effective analysis, $\mathrm{CUA}=$ cost-utility analysis, $\mathrm{CBA}=$ cost - benefit analysis, $\mathrm{CCA}=$ cost-consequence analysis.

Table 2a: Summary of Pharmacoeconomic Studies (CMA=cost-minimization analysis).

\begin{tabular}{|c|c|c|c|c|c|c|}
\hline Ref. & Drug/Treatment Arms & $\mathrm{n} / \mathrm{D}^{*}$ & Method* & $\begin{array}{l}\text { Outcome } \\
\text { Measures }\end{array}$ & $\begin{array}{l}\text { Comparison of both } \\
\text { total cost } A \text { and } B\end{array}$ & Results/Comments \\
\hline 1 & $\begin{array}{l}1 . \\
2 .\end{array}$ & & & $\begin{array}{l}1 . \\
2 .\end{array}$ & & \\
\hline 2 & $\begin{array}{l}1 . \\
2 .\end{array}$ & & & $\begin{array}{l}1 . \\
2 .\end{array}$ & & \\
\hline 3 & $\begin{array}{l}1 . \\
2 .\end{array}$ & & & $\begin{array}{l}1 . \\
2 .\end{array}$ & & \\
\hline \multicolumn{7}{|c|}{${ }^{*} \mathbf{n} / \mathbf{D}^{*}:$ Number of patients/ Duration of the study } \\
\hline
\end{tabular}


Table 2b: Summary of Pharmacoeconomic Studies (CBA=cost-benefit analysis).

\begin{tabular}{|c|c|c|c|c|c|c|}
\hline Ref. & $\begin{array}{c}\text { Drug/Treatment } \\
\text { Arms }\end{array}$ & $\mathrm{n} / \mathrm{D}^{*}$ & Method* & $\begin{array}{c}\text { Outcome } \\
\text { Measures }\end{array}$ & $\begin{array}{c}\text { Net Benefit= } \\
\text { Total Benefit- Total Cost }\end{array}$ & $\begin{array}{c}\text { Cost Benefit Ratio= } \\
\text { Total Benefit/Total } \\
\text { Costs }\end{array}$ \\
\hline 1 & 1. & & & 1. & & \\
\hline 2. & 1. & & 2. & & \\
\hline 3 & 2. & & 1. & & \\
\hline
\end{tabular}

${ }^{*} \mathbf{n} / \mathbf{D}^{*}$ : Number of patients/ Duration of the study

${ }^{*}$ Method abbreviations: mainly evaluation of programs in medical or pharmacy (vaccines, pharmacokinetics, ADIS,...) either one or two comparable program

Discount rate (5-20\%), if the ratio more 2:1 that main more saving money

Table 2c: Summary of Pharmacoeconomic Studies (CEA= cost-effective analysis).

\begin{tabular}{|c|c|c|c|c|c|c|}
\hline Ref. & Drug/Treatment Arms & $\mathrm{n} / \mathrm{D}^{*}$ & Method* & $\begin{array}{c}\text { Outcome } \\
\text { Measures }\end{array}$ & $\begin{array}{c}\text { Average Cost } \\
\text { per cure for each } \\
\text { medications }\end{array}$ & $\begin{array}{c}\text { Incremental C/E } \\
\text { ratio }\end{array}$ \\
\hline 1 & 1. & & & 1. & 1. & \\
\hline 2 & 2. & & 2. & 1. & \\
\hline 3 & 2. & & 1. & 2. & \\
\hline & 2. & & 2. & 2. & \\
\hline
\end{tabular}

${ }^{\star} \mathbf{n} / \mathbf{D}^{\star}$ : Number of patients/ Duration of the study

${ }^{*}$ Method abbreviations: mainly evaluation of two medication with different cost and efficacy

Discount rate (5-20\%),

Average Cost per cure $=$ Total Cost to treat Number of patients/effective rate percentages

Incremental $\mathrm{C} / \mathrm{E}$ ratio= Total Cost to treat Number of patients between medications $(\mathrm{A}-\mathrm{B}) /$ effective rate percentages between medications (A-B).

Table 2d: Summary of Pharmacoeconomic Studies (CUA=cost-utility analysis).

\begin{tabular}{|c|c|c|c|c|c|c|}
\hline Ref. & Drug/Treatment Arms & $\mathrm{n} / \mathrm{D}^{*}$ & Method* & $\begin{array}{c}\text { Outcome } \\
\text { Measures }\end{array}$ & QALYs & Results/Comments \\
\hline 1 & 1. & & & 1. & & \\
\hline 2 & 2. & & & 2. & \\
& 1. & & 1. & & \\
\hline 3 & 2. & & 1. & & \\
& 2. & & 2. & & \\
\hline
\end{tabular}

${ }^{\star} \mathbf{n} / \mathbf{D}^{*}$ : Number of patients/ Duration of the study

${ }^{*}$ Method abbreviations:, , mainly evaluation of two medication with different Length of Life and Health Quality of that Life

Discount rate (5-20\%),

Quality Adjusted Life-years (QALYs), one full healthy year of life is scored as 1.0, the sum are additive years

QALYs measured by completion rating scales (Standard Gamble, Trade-OFFS). 
Table 3: Summary of Cost Analysis.

\begin{tabular}{|c|c|c|c|c|c|c|c|}
\hline Ref & $\begin{array}{c}\text { Generic Name } \\
\text { (Manufacturer) }\end{array}$ & Dose & $\begin{array}{c}\text { Cost/Unit } \\
\text { SFDA }\end{array}$ & $\begin{array}{c}\text { Cost/Unit } \\
\text { GCC }\end{array}$ & $\begin{array}{c}\text { Cost/ Unit } \\
\text { USA }\end{array}$ & $\begin{array}{c}\text { Cost/ Unit } \\
\text { UK }\end{array}$ & $\begin{array}{c}\text { Cost/ Unit } \\
\text { Canada }\end{array}$ \\
\hline 1 & Requested drug & & & & & & \\
\hline 2 & Comparator drug \# 1 & & & & & & \\
\hline 3 & Comparator drug \# 2 & & & & & & \\
\hline 4 & Comparator drug\# 3 & & & & & & \\
\hline 5 & Comparator drug\# 4 & & & & & & \\
\hline
\end{tabular}

Table 4: Type of Pharmacoeconomic Evaluation.

\begin{tabular}{|l|l|}
\hline$\square$ Clinical outcomes studies & $\square$ Patient-reported outcomes studies \\
\hline$\square$ Compliance/adherence studies & $\square$ Quality of life studies \\
\hline$\square$ Cost studies & $\square$ Utility studies \\
\hline$\square$ Health policy studies & $\square$ Using real-world data studies \\
\hline$\square$ Health technology assessment(HTA) & $\square$ Health care decisions studies \\
\hline$\square$ Outcomes research issues & $\square$ Others \\
\hline$\square$ Patient-preferences studies & \\
\hline
\end{tabular}

Table 5: Summary of Pharmacoeconomic Analysis.

\begin{tabular}{|c|c|c|c|c|c|c|c|c|}
\hline Ref & $\begin{array}{c}\text { Generic Name } \\
\text { (Manufacturer) }\end{array}$ & Dose & $\begin{array}{c}\text { Cost/ } \\
\text { Unit }\end{array}$ & $\begin{array}{c}\text { Support } \\
\text { Therapy }\end{array}$ & $\begin{array}{c}\text { Inpatient + } \\
\text { Outpatient } \\
\text { Cost }\end{array}$ & $\begin{array}{c}\text { Cost Drug } \\
\text { Related } \\
\text { Problems }\end{array}$ & $\begin{array}{c}\text { Total } \\
\text { number of } \\
\text { patients }\end{array}$ & $\begin{array}{c}\text { Total } \\
\text { Cost }\end{array}$ \\
\hline $\mathbf{1}$ & Requested drug & & & & & & & \\
\hline 2 & Comparator drug \# 1 & & & & & & & \\
\hline 3 & Comparator drug \# 2 & & & & & & & \\
\hline 4 & Comparator drug \# 3 & & & & & & & \\
\hline 5 & Comparator drug \# 4 & & & & & & & \\
\hline
\end{tabular}

Table 6: Summary of Pharmacoeconomic Drug Related Problem Analysis.

\begin{tabular}{|c|c|c|c|c|c|c|c|c|}
\hline Ref & $\begin{array}{c}\text { Generic Name } \\
\text { (Manufacturer) }\end{array}$ & Dose & $\begin{array}{c}\text { Cost/ } \\
\text { Unit }\end{array}$ & $\begin{array}{c}\text { Cost } \\
\text { ADR }\end{array}$ & $\begin{array}{c}\text { Cost } \\
\text { Medication } \\
\text { Errors }\end{array}$ & $\begin{array}{c}\text { Cost other } \\
\text { Drug Related } \\
\text { Problems }\end{array}$ & $\begin{array}{c}\text { Total } \\
\text { number of } \\
\text { patients }\end{array}$ & Total Cost \\
\hline 1 & Requested drug & & & & & & & \\
\hline 2 & Comparator drug\# 1 & & & & & & & \\
\hline 3 & Comparator drug\# 2 & & & & & & & \\
\hline 4 & Comparator drug\#3 & & & & & & & \\
\hline 5 & Comparator drug\# 4 & & & & & & & \\
\hline
\end{tabular}


Table 7: Utility Rank.

\begin{tabular}{|c|c|c|c|c|c|c|}
\hline Ref & $\begin{array}{l}\text { Generic Name } \\
\text { (Manufacturer) }\end{array}$ & Cost/ Unit & $\begin{array}{c}\text { Total number of } \\
\text { patients }\end{array}$ & Total Cost & Budget impact & Comments \\
\hline 1 & Requested drug & & & & & \\
\hline 2 & Comparator drug \# 1 & & & & & \\
\hline 3 & Comparator drug \# 2 & & & & & \\
\hline 4 & Comparator drug \# 3 & & & & & \\
\hline
\end{tabular}

Therapeutic:

Rank= 1 if large randomized clinical trials demonstrate clear -cut therapeutic advantage (enhanced efficacy and /or reduced toxicity) over available modalities and use of drug will lead to clinically significant improvement in patient mortality, morbidity or quality of life.

Rank= 2 if clinical studies indicate therapeutic advantage over available modalities but there is questionable / marginal improvement in patient outcome and /or efficacy advantage is somewhat offset by toxicity disadvantage.

Rank $=3$ if no therapeutic advantage but secondary chrematistics confer some advantage (e.g dosage form, route / frequency of administration, pharmacokinetics, convenience).

Rank $=4$ if no demonstrated advantage over currently available modalities.

Cost :

Rank= $\mathrm{A}$ if addition of drug will significantly reduce direct cost to hospital.

Rank= B if addition of drug will modestly reduce direct costs to hospital.

Rank $=\mathrm{C}$ if addition of drug will have minimal direct cost impact (i.e., less than 20,000 per year.

Rank= D if addition of drug will modestly increase direct costs to hospital (i.e., 20,000 SR to 60,000 SR per year).

Rank= if addition of drug will significantly increase direct cost to hospital (i.e., more than 60.000 SR per year).

\section{Conclusions:}

\section{References:}

\begin{tabular}{|l|l|}
\hline 1 & \\
\hline 2 & \\
\hline 3 & \\
\hline 4 & \\
\hline 5 & \\
\hline 6 & \\
\hline
\end{tabular}

